\title{
AGE RELATED CHANGES IN MUSCLE PROTEIN DEGRADATION
}

\author{
S. MOHAN and E. RADHA \\ Department of Zoology, Bangalore University, Bangalore-560001 (India)
}

(Received April 23, 1976; in revised form January 6, 1977)

\section{SUMMARY}

In vitro autolytic degradation of sarcoplasmic proteins in red, white and cardiac muscles increases with advance in age and with increase in temperature, the rate varying with age. Higher activity is seen in the alkaline range in all age groups. $\mathrm{Ca}^{2+}$ activated proteolytic activity also increases with advance in age.

\section{INTRODUCTION}

Gutmann et al. [1-4] have shown significant similarities between denervated and senile muscles in the metabolic changes. Increased proteolytic activity seen in denervated and senile muscles is also characteristic of muscular atrophy. Increased in vitro autolytic $[5,6]$ and $\mathrm{Ca}^{2+}$ activated proteolytic activity of sarcoplasmic proteins following denervation have been reported. The present study is to see whether the muscles of old animals behave in a manner similar to denervated muscles with respect to changes in in vitro autolytic activity and $\mathrm{Ca}^{2+}$ activated proteolytic activity of sarcoplasmic proteins and also to find the functional relationship, if any, of the latter enzymes with ageing.

\section{MATERIALS AND METHODS}

Effect of temperature on in vitro autolytic activity

Red (soleus), white (extensor digitorum longus) and cardiac muscles of albino rats, Wistar strain aged 5, 10, 15, 20 and 25 months were used for the study. For in vitro autolysis, the animals were decapitated, the muscles were excised, chilled, weighed and homogenized immediately. The muscle homogenate in $0.25 M$ sucrose ( $\mathrm{pH} \mathrm{7)}$ was centrifuged at $600 \times \mathrm{g}$ for $20 \mathrm{~min}$ to separate the sarcoplasmic proteins (supernatant) from contractile and collagenous proteins (sediments rapidly at $600 \times \mathrm{g}$ ). $1 \mathrm{ml}$ of the supernatant was incubated in closed tubes at the desired temperature $\left(0^{\circ}, 10^{\circ}, 20^{\circ}, 30^{\circ}\right.$ and $37^{\circ} \mathrm{C}$ ) for $2 \mathrm{~h}$ as described earlier [8]. Controls were run simultaneously at $0 \mathrm{~min}$ of incubation. The autolytic activity was stopped with $1 \mathrm{ml}$ of $10 \% \mathrm{TCA}$ and centrifuged. 
The supernatant was neutralized with $0.5 \mathrm{~N} \mathrm{NaOH}$ and the total free amino acid content was estimated [9]. The protein content was estimated by the method of Layne [10]. $Q_{10}$ was calculated for different ranges of temperature according to van't Hoff's equation [11].

pH and in vitro autolytic activity

The muscle homogenates were mixed with an equal volume of buffer of $0.2 \mathrm{M}$ potassium acid phthalate, potassium phosphate and Tris buffer (pH 2-9) [12] and incubated in a water bath at $37^{\circ} \mathrm{C}$ for $2 \mathrm{~h}$; at the end of the incubation period, $1 \mathrm{ml}$ of $10 \%$ TCA was added to stop the activity and the supernatant was analyzed for total free amino acid content [9]. An unincubated, TCA denatured supernatant served as control.

\section{$\mathrm{Ca}^{2+}$ activated proteolytic activity}

The sucrose homogenate of sarcoplasmic proteins was centrifuged at $1000 \times g$ for $20 \mathrm{~min}$ at $4{ }^{\circ} \mathrm{C}$ to remove contaminating contractile, fibrous and $Z$-line proteins and then dialyzed for $2 \mathrm{~h}$ against $0.25 \mathrm{M}$ sucrose. $1 \mathrm{ml}$ dialyzate, $1 \mathrm{ml}$ of $1 \%$ casein in $5 \mathrm{mM}$ $\mathrm{NaHCO}_{3}$ and $1 \mathrm{ml}$ of $0.01 \mathrm{M} \mathrm{CaCl}_{2}$ were mixed and incubated at $37{ }^{\circ} \mathrm{C}$ for $3 \mathrm{~h}$. At the end of the incubation period, the protein was precipitated with the addition of $2 \mathrm{ml}$ of $10 \% \mathrm{TCA}$. The clear supernatant obtained after centrifugation at $600 \times \mathrm{g}$ for $10 \mathrm{~min}$ was

\section{TABLE I}

EFFECT OF TEMPERATURE ON IN VITRO AUTOLYTIC DEGRADATION OF SARCOPLASMIC PROTEINS IN RED, WHITE AND CARDIAC MUSCLES OF RATS DURING AGEING

Values are represented as mean \pm SD of 7 observations. Autoly tic activity is expressed as $\mu \mathrm{g}$ of amino acid released/mg protein/h.

\begin{tabular}{|c|c|c|c|c|c|c|}
\hline \multirow{2}{*}{$\begin{array}{l}\text { Temp. } \\
\text { PC) }\end{array}$} & \multirow{2}{*}{$\begin{array}{l}\text { Nature of } \\
\text { muscle }\end{array}$} & \multicolumn{5}{|c|}{ Age (months) } \\
\hline & & 5 & 10 & 15 & 20 & 25 \\
\hline \multirow[t]{3}{*}{0} & Red & $8.5 \pm 1.6$ & $13.0 \pm 1.4$ & $12.3 \pm 1.2$ & $14.4 \pm 0.9$ & $14.9 \pm 1.1$ \\
\hline & White & $6.0 \pm 0.6$ & $11.4 \pm 0.9$ & $9.6 \pm 2.2$ & $15.1 \pm 0.7$ & $15.6 \pm 1.6$ \\
\hline & Cardiac & $7.3 \pm 1.4$ & $12.2 \pm 1.8$ & $11.8 \pm 2.2$ & $14.6 \pm 1.6$ & $15.8 \pm 1.3$ \\
\hline \multirow[t]{3}{*}{10} & Red & $11.7 \pm 0.8$ & $14.6 \pm 1.0$ & $16.8 \pm 1.8$ & $20.5 \pm 1.0$ & $20.1 \pm 1.2$ \\
\hline & White & $9.3 \pm 1.2$ & $15.3 \pm 2.2$ & $14.8 \pm 1.8$ & $18.5 \pm 1.9$ & $19.9 \pm 2.4$ \\
\hline & Cardiac & $10.5 \pm 1.0$ & $14.9 \pm 1.3$ & $16.5 \pm 1.9$ & $17.1 \pm 2.1$ & $19.1 \pm 1.6$ \\
\hline \multirow[t]{3}{*}{20} & Red & $14.8 \pm 0.8$ & $18.6 \pm 1.0$ & $20.5 \pm 1.1$ & $24.5 \pm 1.4$ & $25.6 \pm 1.7$ \\
\hline & White & $12.8 \pm 1.0$ & $19.8 \pm 0.6$ & $19.7 \pm 2.5$ & $20.3 \pm 1.7$ & $22.0 \pm 1.1$ \\
\hline & Cardiac & $12.1 \pm 0.6$ & $15.8 \pm 1.6$ & $19.5 \pm 1.6$ & $21.7 \pm 1.9$ & $22.8 \pm 2.3$ \\
\hline \multirow[t]{3}{*}{30} & Red & $18.5 \pm 1.1$ & $20.9 \pm 1.0$ & $23.1 \pm 2.1$ & $26.1 \pm 2.8$ & $28.2 \pm 2.3$ \\
\hline & White & $16.8 \pm 0.9$ & $22.5 \pm 1.2$ & $24.8 \pm 2.5$ & $23.3 \pm 1.2$ & $24.4 \pm 2.5$ \\
\hline & Cardiac & $16.1 \pm 1.7$ & $18.9 \pm 2.3$ & $22.3 \pm 1.3$ & $23.4 \pm 1.3$ & $24.8 \pm 2.6$ \\
\hline \multirow[t]{3}{*}{37} & Red & $19.2 \pm 1.8$ & $22.4 \pm 0.8$ & $25.5 \pm 1.5$ & $28.4+2.1$ & $32.4 屯 3.1$ \\
\hline & White & $17.7 \pm 1.3$ & $24.0 \pm 1.3$ & $25.3 \pm 2.4$ & $24.1 \pm 3.1$ & $27.2 \pm 2.1$ \\
\hline & Cardiac & $18.2 \pm 1.2$ & $21.2 \pm 2.1$ & $24.3 \pm 2.0$ & $26.2 \pm 2.6$ & $30.7 \pm 3.0$ \\
\hline
\end{tabular}


neutralized with $0.5 \mathrm{~N} \mathrm{NaOH}$ and assayed for total free amino acid content [9]. The protein content of the homogenate prior to incubation was estimated according to the method of Layne [10]. The proteolytic activity in the assay medium was corrected to the in vitro autolytic degradation and expressed as $\mu \mathrm{g}$ of amino acid released $/ \mathrm{mg}$ initial homogenate protein/h.

\section{RESULTS}

Table I shows the in vitro autolytic activity in red, white and cardiac muscles of rat as a function of temperature during ageing. The in vitro autolytic degradation of sarcoplasmic proteins increases with increase in temperature but the rate of increase varies with age. $Q_{10}$ for in vitro autolytic activity increases upto 15 months in white muscle and upto 20 months in red and cardiac muscles. There is a sharp decrease at 25 months age in all the three muscles (Fig. 1). With advance in age, there is an increase in in vitro autolytic degradation of sarcoplasmic proteins in white, red and cardiac muscles (Fig. 2). The activity increases by $70 \%$ in red and cardiac and $54 \%$ in white muscle as the age advances from 5 months to 25 months (Fig. 3). Table II shows the influence of $\mathrm{pH}$ on proteolysis of the endogenous substrate. This indirectly suggests the effect of $\mathrm{pH}$ on cathepsin activity as the in vitro autolysis of the buffered homogenate is considered to be mostly due to intracellular cathepsins. Higher in vitro autolytic activity is seen in the alkaline range in all the three muscles of all five age groups. The reason for the peak seen at $\mathrm{pH} 4$ in 5 month old animals needs further investigation with a different batch of rats. The $\mathrm{Ca}^{2+}$ activated proteolytic activity increases by two fold during ageing, the red muscle showing higher activity than the white (Fig. 4).

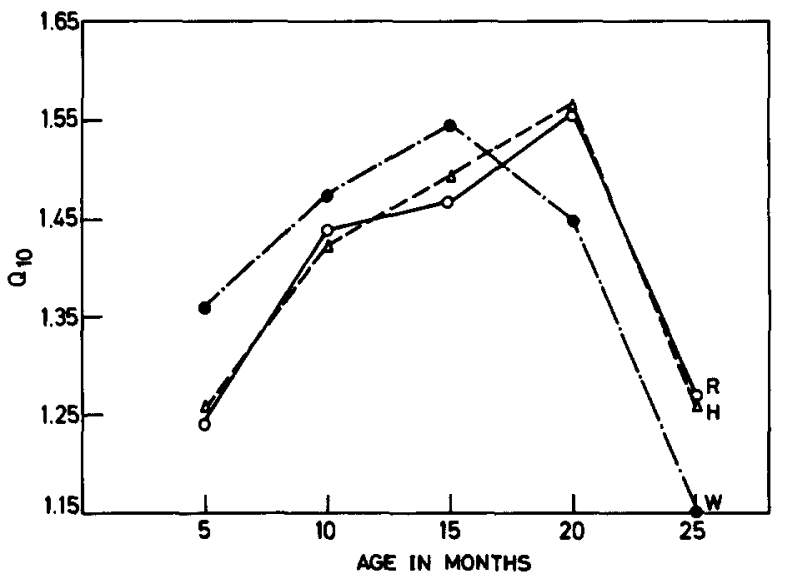

Fig. 1. $Q_{10}$ for in vitro autolytic activity. $\mathrm{R}=$ red muscle (soleus); $\mathrm{W}=$ white muscle (extensor digitorum longus), $\mathrm{H}=$ cardiac muscle. Values are represented as mean \pm of 7 observations. 


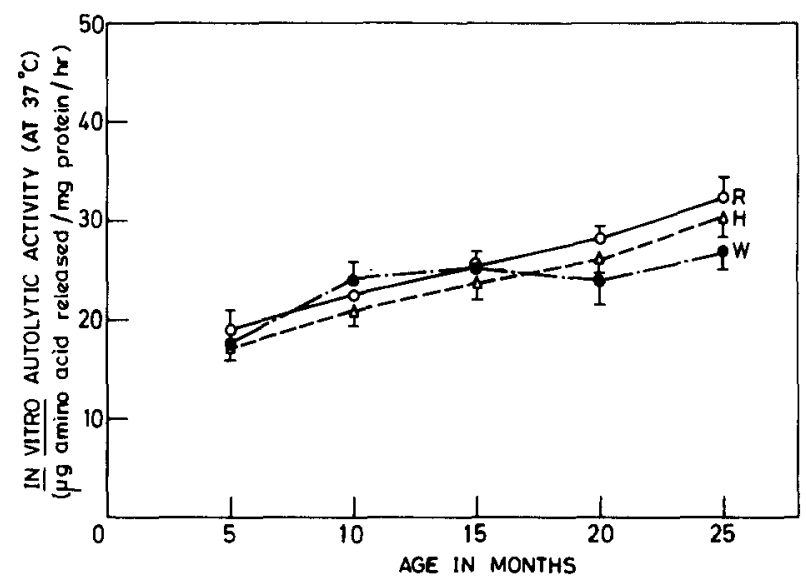

Fig. 2. In vitro autolytic degradation of sarcoplasmic proteins (at $37^{\circ} \mathrm{C}$ ). $\mathrm{R}=$ red muscle (soleus); $\mathrm{W}=$ white muscle (extensor digitorum longus), $\mathrm{H}=$ cardiac muscle. Values are represented as mean \pm of 7 observations.

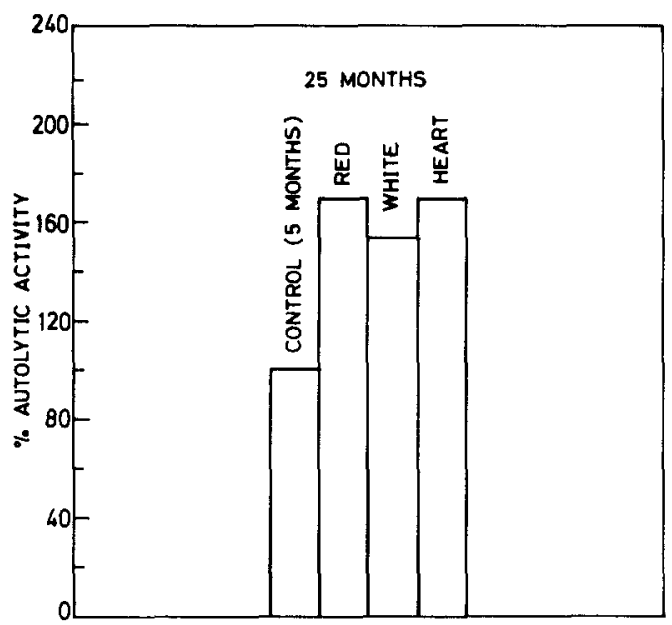

Fig. 3. Percentage increase in autolytic activity as the age advances from 5 months to 25 months. $\mathrm{R}=$ red muscle (soleus); $\mathrm{W}=$ white muscle (extensor digitorum longus), $\mathrm{H}=$ cardiac muscle. Values are represented as mean \pm of 7 observations.

\section{DISCUSSION}

The increase in in vitro autolytic and $\mathrm{Ca}^{2+}$ activated proteolytic activity in red, white and cardiac muscles during ageing is concomitant with the results obtained for denervated muscle $[5,6]$. There is no significant difference in in vitro autolytic degradation of the sarcoplasmic proteins between the three muscles in case of 5, 10 and 15 month old whereas at 20 and 25 months the activity is more in red than in white muscle. The increased in vitro autolytic activity of sarcoplasmic proteins in red, white and cardiac 
TABLE II

EFFECT OF pH ON IN VITRO AUTOLYTIC DEGRADATION OF SARCOPLASMIC PROTEINS IN RED, WHITE AND CARDIAC MUSCLES OF RATS DURING AGEING

Values are represented as mean $\pm \mathrm{SD}$ of 7 observations. Autolytic activity is expressed as $\mu \mathrm{g}$ of amino acid released $/ \mathrm{mg}$ protein $/ \mathrm{h}$.

\begin{tabular}{|c|c|c|c|c|c|c|}
\hline \multirow[t]{2}{*}{$p H$} & \multirow{2}{*}{$\begin{array}{l}\text { Nature of } \\
\text { muscle }\end{array}$} & \multicolumn{5}{|c|}{ Age (months) } \\
\hline & & 5 & 10 & 15 & 20 & 25 \\
\hline \multirow[t]{3}{*}{2} & Red & $1.6 \pm 0.3$ & $2.3 \pm 0.3$ & $3.3 \pm 0.3$ & $3.8 \pm 0.4$ & $3.8 \pm 0.3$ \\
\hline & White & $2.1 \pm 0.4$ & $2.9 \pm 0.3$ & $2.2 \pm 0.2$ & $2.5 \pm 0.1$ & $3.3 \pm 0.7$ \\
\hline & Cardiac & $2.3 \pm 0.5$ & $2.9 \pm 0.6$ & $2.0 \pm 0.1$ & $3.4 \pm 0.4$ & $3.5 \pm 0.4$ \\
\hline \multirow[t]{3}{*}{3} & Red & $3.3 \pm 0.3$ & $3.1 \pm 1.1$ & $6.0 \pm 0.8$ & $5.4 \pm 0.4$ & $6.4 \pm 0.5$ \\
\hline & White & $3.9 \pm 0.6$ & $4.0 \pm 0.4$ & $3.9 \pm 0.2$ & $5.0 \pm 0.6$ & $4.2 \pm 0.7$ \\
\hline & Cardiac & $4.0 \pm 0.2$ & $2.9 \pm 0.3$ & $3.2 \pm 0.1$ & $4.2 \pm 0.5$ & $6.8 \pm 0.6$ \\
\hline \multirow[t]{3}{*}{4} & Red & $8.8 \pm 1.7$ & $4.7 \pm 0.7$ & $6.6 \pm 1.1$ & $10.3 \pm 1.4$ & $9.7 \pm 0.8$ \\
\hline & White & $7.2 \pm 0.8$ & $3.4 \pm 0.7$ & $5.8 \pm 0.5$ & $4.8 \pm 0.7$ & $7.2 \pm 0.9$ \\
\hline & Cardiac & $6.7 \pm 0.7$ & $5.0 \pm 0.5$ & $5.1 \pm 0.6$ & $7.0 \pm 0.8$ & $10.0 \pm 0.7$ \\
\hline \multirow[t]{3}{*}{5} & Red & $6.3 \pm 1.1$ & $6.8 \pm 1.1$ & $9.7 \pm 1.3$ & $11.3 \pm 1.6$ & $12.7 \pm 0.9$ \\
\hline & White & $5.9 \pm 1.4$ & $4.4 \pm 0.8$ & $7.2 \pm 0.6$ & $7.4 \pm 0.8$ & $9.0 \pm 0.8$ \\
\hline & Cardiac & $5.6 \pm 0.3$ & $6.6 \pm 0.6$ & $6.5 \pm 0.8$ & $11.0 \pm 1.1$ & $13.2 \pm 0.8$ \\
\hline \multirow[t]{3}{*}{6} & Red & $7.9 \pm 0.9$ & $9.5 \pm 0.8$ & $12.4 \pm 1.6$ & $14.3 \pm 1.7$ & $16.1 \pm 1.3$ \\
\hline & White & $6.0 \pm 1.5$ & $6.9 \pm 1.0$ & $9.0 \pm 0.9$ & $10.6 \pm 0.7$ & $13.2 \pm 1.4$ \\
\hline & Cardiac & $7.1 \pm 0.6$ & $7.3 \pm 1.4$ & $8.6 \pm 0.7$ & $12.6 \pm 1.5$ & $15.2 \pm 1.1$ \\
\hline \multirow[t]{3}{*}{7} & Red & $10.8 \pm 1.0$ & $12.4 \pm 1.6$ & $14.3 \pm 0.7$ & $17.4 \pm 1.2$ & $20.4 \pm 1.9$ \\
\hline & White & $8.2 \pm 1.0$ & $8.3 \pm 1.0$ & $11.5 \pm 0.7$ & $13.6 \pm 1.5$ & $17.6 \pm 0.8$ \\
\hline & Cardiac & $8.2 \pm 0.8$ & $9.4 \pm 0.9$ & $10.1 \pm 0.7$ & $14.5 \pm 1.5$ & $17.5 \pm 1.2$ \\
\hline \multirow[t]{3}{*}{8} & Red & $11.2 \pm 1.4$ & $12.1 \pm 1.5$ & $15.6 \pm 1.0$ & $20.0 \pm 1.6$ & $24.8 \pm 1.1$ \\
\hline & White & $9.0 \pm 0.4$ & $9.8 \pm 0.8$ & $12.0 \pm 0.9$ & $16.7 \pm 1.2$ & $21.5 \pm 1.7$ \\
\hline & Cardiac & $10.7 \pm 1.2$ & $10.8 \pm 0.4$ & $12.3 \pm 0.5$ & $18.7 \pm 1.6$ & $22.3 \pm 1.3$ \\
\hline \multirow[t]{3}{*}{9} & Red & $11.6 \pm 0.8$ & $12.8 \pm 1.2$ & $14.5 \pm 0.9$ & $20.4 \pm 1.3$ & $23.6 \pm 0.9$ \\
\hline & White & $8.5 \pm 0.5$ & $8.7 \pm 1.1$ & $9.2 \pm 0.5$ & $16.7 \pm 0.7$ & $20.0 \pm 0.7$ \\
\hline & Cardiac & $10.5 \pm 0.7$ & $11.0 \pm 1.2$ & $12.0 \pm 0.4$ & $18.7 \pm 1.8$ & $22.5 \pm 0.5$ \\
\hline
\end{tabular}

muscles during ageing could be attributed to increased cathepsin activity as the autolysis of the homogenate is considered to be mostly due to intracellular cathepsins. Two types of cathepsins are reported to occur in the skeletal muscle, one with an optimum activity in the acid range [13], and the other in the alkaline range [14]; however, these studies were not with reference to ageing.

Increase in in vitro autolytic and $\mathrm{Ca}^{2+}$ activated proteolytic activity of sarcoplasmic proteins shown by the present results can be related to the increase in degradation of proteins during ageing. Senile and denervated muscles have similar pattern of change with reference to autolytic and proteolytic activity. The analogy of metabolic changes in muscles of old animals and those of denervated muscles is further strengthened by the present study. 


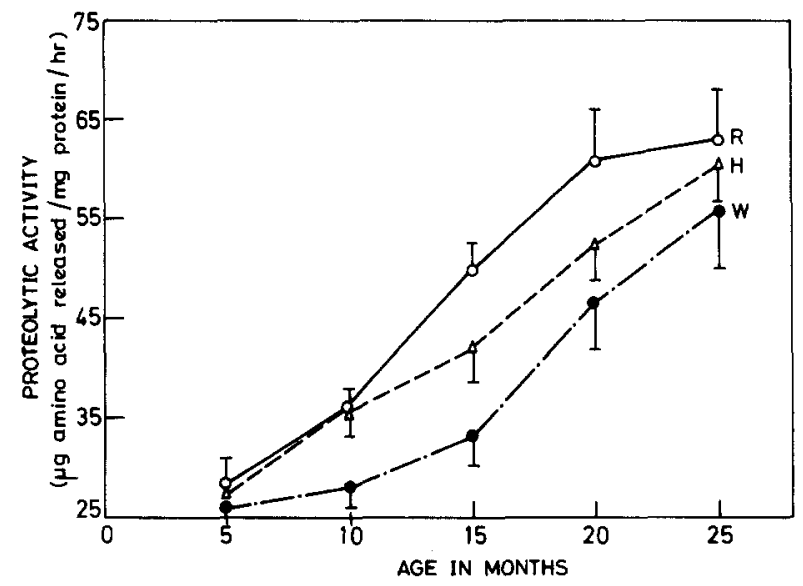

Fig. 4. $\mathrm{Ca}^{2+}$ activated proteolytic activity of sarcoplasmic proteins. $\mathrm{R}=$ red muscle (soleus); $\mathrm{W}=$ white muscle (extensor digitorum longus), $\mathrm{H}=$ cardiac muscle. Values are represented as mean $\pm \mathrm{SD}$ of 7 observations.

\section{ACKNOWLEDGEMENTS}

We are very grateful to Professor B. C. Abbott, University of Southern California for his valuable suggestions and the Council of Scientific and Industrial Research for financial assistance.

\section{REFERENCES}

1 Z. Drahota and E. Gutmann, The influence of age on the course of reinnervation of muscle, Gerontologia, 5 (1961) 88.

2 E. Gutmann, I. Hajek and I. Syrovy, Metabolic relations between nerve and muscle cell in denervation and reinnervation in young and old animals, Fed. Proc. Fed. Am. Soc. Exp. Biol., 23 (1964) 419.

3 I. Syrovy, I. Hajek and E. Gutmann, Proteolytic activity of isolated protein fractions in normal and denervated muscle, Physiol. Bohemoslov., 14 (1965) 12-16.

4 I. Hajek, E. Gutmann and I. Syrovy, Proteolytic activity in muscles of old animals, Physiol. Bohemoslov., 14 (1965) 481-487.

5 R. R. Kohn, Denervation muscle atrophy: an autoly tic system in vitro, Am. J. Pathol, 47 (1965) 315-323.

6 R. V. Krishnamoorthy, D. Chengal Raju and V. Chandrasekaram, Demonstration of increased in vitro autolytic activity in a denervated muscle of frog, Experientia, 27 (1971) 1408-1409.

7 R. V. Krishnamoorthy, Increased proteolytic activty in muscular atrophy of denervated frogs, Enzymologia, 41 (1971) 249-259.

$8 \mathrm{~S}$. Mohan and E. Radha, In vitro autolytic activity in aging rat muscles, Vignana Bharathi, 1 (1975) 119-122.

9 S. Moore and W. H. Stein, A modified ninhydrin reagent for photometric determination of amino acids and related compounds, J. Biol. Chem., 211 (1954) 907-913.

10 E. Layne, Spectrophotometric and turbidimetric method for measuring proteins, in S. P. Colowick and N. O. Kaplan (eds.), Methods in Enzymology, Vol. III, Academic Press, New York, 1957, p. 457. 
11 C. L. Prosser and F. A. Brown, Comparative Animal Physiology, Toppan, Tokyo, 1961, p. 239.

12 G. Gomori, Preparation of buffers for use in enzyme studies, in S. P. Colowick and N. O. Kaplan (eds.), Methods in Enzymology, Vol. I, Academic Press, New York, 1955, pp. 138-146.

13 Y. E. Snoke and H. Neurath, The proteoly tic activity of the striated rabbit muscle, J. Biol. Chem., 187 (1950) 127-135.

14 T. R. Koszalka and L. L. Miller, Proteolytic activity of rat skeletal muscle, J. Biol. Chem., 665 (1965) 672 . 